Sains Malaysiana 47(1)(2018): 123-129

http://dx.doi.org/10.17576/jsm-2018-4701-15

\title{
Bone Mineral Density and Associated Risk Factors among Female Athletes: A Cross-Sectional Study
}

(Ketumpatan Mineral Tulang dan Faktor Risiko yang Berkaitan dalam Kalangan Atlet Wanita: Suatu Kajian Rentas)

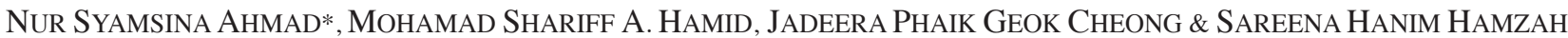

\section{ABSTRACT}

Menstrual irregularity and disordered eating were previously identified as risk factors for low bone mineral density $(B M D)$ in female athletes. Therefore, an investigation for more potential factors that could be associated with low BMD among Malaysian female athletes is required. The aim of this study was to assess the association of BMD with energy availability, body weight, body fat, estrogen level and bone loading status in female athletes and to what extent those factors predict BMD. Energy intake and expenditure, body weight, Bone Physical Activity Questionnaire (BPAQ) score and estrogen level were determined from 85 female athletes aged 18-30 years in this cross-sectional study. Bone mineral density was measured by using an ultrasound bone densitometry device at the calcaneus bone. The female athletes' body weight and fat percentage were $56 \pm 9 \mathrm{~kg}$ and $27 \pm 6 \%$, respectively and they were all eumenorrheic. Fifty three percent of them had low BMD (z-score < 0). Their mean energy intake (1291 $33 \mathrm{kcal} /$ day) was lower than energy expenditure (1807 $\pm 34 \mathrm{kcal} /$ day) which resulted in a low energy availability $(29 \pm 1 \mathrm{kcal} /$ day $/ \mathrm{kg}$ FFM). BMD was positively associated with BPAQ score $(\mathrm{r}=0.4, \mathrm{p}=0.000)$ and body weight $(\mathrm{r}=0.3, \mathrm{p}=0.005)$ but negatively associated with energy expenditure $(\mathrm{r}=-0.4, \mathrm{p}=0.000)$. There was no association of BMD with energy intake, energy availability, body fat percentage and estrogen level. In conclusion, BMD was associated with energy expenditure, body weight and BPAQ score among female athletes. Regression analysis showed that energy expenditure and BPAQ score were the main factors to predict BMD.

Keywords: Energy intake; exercise; hormone; nutrient; physical activity

ABSTRAK

Haid tidak teratur dan gangguan pemakanan merupakan faktor risiko yang dikenal pasti untuk ketumpatan mineral tulang (KMT) yang rendah dalam kalangan atlet wanita. Oleh itu, lebih banyak kajian bagi faktor yang berpotensi dikaitkan dengan KMT yang rendah dalam kalangan atlet wanita Malaysia diperlukan. Tujuan kajian ini adalah untuk menilai perkaitan antara KMT dengan ketersediaan tenaga, berat badan, lemak badan, paras estrogen dan status bebanan tulang dalam atlet wanita dan seterusnya faktor-faktor yang meramalkan KMT. Pengambilan dan penggunaan tenaga, berat badan, Soalselidik Aktiviti Fizikal Tulang (SAFT) dan tahap estrogen telah dikaji daripada 85 atlet wanita berusia 18-30 tahun dalam kajian keratan rentas ini. Kepadatan tulang mineral diukur dengan menggunakan alat densitometri ultrasound tulang pada tulang kalkaneus. Berat badan dan peratusan lemak atlet wanita masing-masing adalah $56 \pm 9$ $\mathrm{kg}$ dan $27 \pm 6 \%$ dan mereka adalah eumenorrheic. $53 \%$ daripada atlet wanita mempunyai KMT (skor $z<0)$ yang rendah.

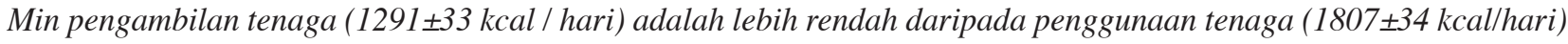

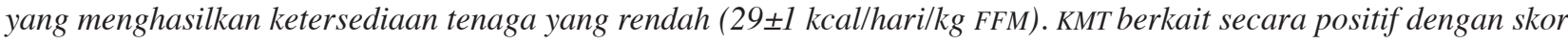
$\operatorname{SAFT}(\mathrm{r}=0.4, \mathrm{p}=0.000)$ dan berat badan $(\mathrm{r}=0.3, \mathrm{p}=0.005)$ tetapi berkait secara negatif dengan penggunaan tenaga $(\mathrm{r}=-$ 0.4, $\mathrm{p}=0.000$ ). Tidak ada perkaitan KMT dengan pengambilan tenaga, ketersediaan tenaga, peratusan lemak badan dan tahap estrogen. Secara kesimpulan, KMT adalah berkait dengan penggunaan tenaga, berat badan dan skor SAFT dalam kalangan atlet wanita. Analisa regresi menunjukkan bahawa penggunaan tenaga dan skor SAFT merupakan faktor utama untuk menjangkakan KMT.

Kata kunci: Aktiviti fizikal; hormon; latihan; nutrien; pengambilan tenaga

\section{INTRODUCTION}

Adequate nutrition is important not only for maintaining good health and optimal sports performance among female athletes, but also for bone health. It has been recommended that the energy requirement for active Malaysian females aged between 19 and 29 years old is $2065 \mathrm{kcal} /$ day (NCCFN 2005). However, it was found that female athletes reported energy intake of less than $2000 \mathrm{kcal} /$ day (Dwyer et al.
2012; Papadopoulou et al. 2012; Shriver et al. 2013) which substantially could not support their strenuous activity and nutritional demands (Reed et al. 2014). Inadequate energy intake could reduce body weight and body fat of female athletes (Hall et al. 2012) leading to reduction of reproductive hormonal secretion especially estrogen which negatively affect bone health (Quah et al. 2009; Rauh et al. 2010). Several recent studies also showed that nutrient 
intake for female athlete mostly lower than recommended in nutritional standard especially in carbohydrate (CHO), protein and fat (Ariel \& Constantini 2012; Shriver et al. 2013) and showed an inadequate intake of calcium and vitamin $\mathrm{D}$ which might affect their bone health (McClung et al. 2014).

The daily total energy expenditure for various sports had been reported to be significantly higher than energy intake among female athletes (Shriver et al. 2013). Low energy intake coupled with high energy expenditure was associated with a condition known as low energy availability (Reed et al. 2014). There is evidence that energy availability below $30 \mathrm{kcal} / \mathrm{kgFFM} /$ day leading to low BMD was mediated by estrogen deficiency in amenorrhea athletes (Yang et al. 2010). In contrast, it also was been shown that the reduction of energy availability reduced the rate of bone mineralization without deteriorating estrogen concentration in the condition of energy deficiency (Ihle \& Loucks 2004). In other word, low BMD could occur in female athletes with normal estrogen level.

Other than energy availability and hormonal factors, a growing body of literature had investigated the association between BMD and bone mechanical loading. Scofield and Hecht (2012) reported that weight-bearing exercises had high bone mechanical loading that could give an advantage for long-term bone health. It had been shown that weight bearing exercise with high impact loading sports such as gymnastics, basketball and volleyball produced a better osteogenic response than sports without impact loading such as swimming, cycling and rowing (Nichols et al. 2007). However, previous study has demonstrated a lower BMD among weight bearing sport that involved in low impact sport (e.g. bowling) and long duration of sport activity (e.g. marathon runners) compared to non-weight bearing sport (Scofield \& Hecht 2012).

Previous study had focused on the factors such as calcium intake, menstrual disturbance and eating disorders to determine the prevalence of BMD among female athletes in Malaysia (Quah et al. 2009). Therefore, more potential factors that could be associated with low BMD needs to be investigated using more comprehensive approaches. The aim of this study was to determine the association of BMD with energy availability, energy intake and expenditure, body weight, body fat percentage, estrogen level and bone loading status and to what extent do these factors predict BMD.

\section{METHODS}

\section{PARTICIPANTS AND RECRUITMENT}

Eighty-five female athletes from higher learning institutions around Lembah Pantai, aged between 18 and 30 years old were recruited in this study. The inclusion criteria used were; healthy, physically active (train or exercise three times per week for at least $60 \mathrm{~min}$ ) and participated in sports competition at university, club or state level for the past 5 years. While the exclusion criteria used were; pregnant, on medication, taking supplements and had any chronic diseases such as diabetes, stroke or high blood pressure. Details of the study and the procedures involved were explained to the participants. This study was conducted with the approval of University Malaya Research Ethics Committee (UM.TNC2/RC/H\&E/ UMREC-43) and the participants provided written consent.

\section{STUDY DESIGN}

This study was a cross-sectional study that was conducted to investigate the factors that could be associated with bone health among female athletes. Participants were recruited via posters and social media at several higher institutions within Lembah Pantai. The sample size was estimated using G-Power version 3.1.9.2. The G-Power of the study indicated that a minimum sample size of 68 produced $95 \%$ confident interval with effect size of $\mathrm{f}=1.17, \alpha=0.05$ and $1-\beta=0.95$. Mean and standard deviation (SD) of energy expenditure were used based on a previous study conducted by Ismail et al. (1997). An additional of $20 \%$ participants was included to the calculated sample size to account for the possibility of participants not attending the subsequent follow-up visits. The total calculated sample size for this study was 85 participants. The study was conducted over two sessions with one week apart. In the first session, body weight, body fat percentage and fat free mass were measured using the bioelectrical impedance analysis (SC-330, TANITA, Japan) and height was measured using a portable stadiometer (SECA, Germany). The participants were asked to complete a health screening form, a menstrual history questionnaire and a $24 \mathrm{~h}$ diet recall. Food records and detailed instructions on how to complete the 3-day food record were explained to the participants. For the second session, the participants' basal metabolic rate and BMD were measured. Fasting blood sample was taken from the mid-cubital vein by a qualified phlebotomist. Participants were required to complete the Bone-Specific Physical Activity Questionnaire (BPAQ). In this session, they also returned their completed 3-day food record.

\section{BONE MINERAL DENSITY}

BMD was measured using a portable ultrasound bone densitometer (Furuno CM-200, GB2424276, Japan) at the right side of the calcaneus bone. The precise measurement was accomplished with heel temperature compensation of sos expressed in meter per second $(\mathrm{m} / \mathrm{s})$ and assisted by height adjustable footplate to accurately align a different size heel to the optimized position of the measuring device. Within $10 \mathrm{~s}$, the results were printed out from an on-board printer and displayed on LCD. Z-score was used to categorize subjects into two groups, as recommended by Lewiecki et al. (2004): With those having low bone quality for chronological age classified as z-score $<0$ and the normal group as z-score $\geq 0$. 


\section{ENERGY EXPENDITURE MEASUREMENT AND CALCULATION}

BMR was measured by the indirect calorimetry ventilated hood system (Quark C-PET, COSMED, Italy) which analysed the oxygen consumption and carbon dioxide production from the expired air. The test was carried out in a metabolic room following overnight fast and $24 \mathrm{~h}$ abstention from exercise. For each 30 min BMR measurement, the first 10 min was excluded to ensure steady state values were used and the averaged BMR was calculated. The energy expenditure was estimated by multiplying the BMR value with PAL (Ismail et al. 1997) (PAL=1.7 for female athletes (FAO/WHO/UNU 2004)).

\section{DIETARY INTAKE ASSESSMENT}

$24 \mathrm{~h}$ food recall The participants were required to recall and record all the food and beverages that were consumed within the last $24 \mathrm{~h}$. A food recall kit (bowl size- L, M and $\mathrm{S}$, plate, teaspoon, tablespoon and scoop) was provided to help the participants to determine the amount of food taken.

3-day food record Participants were required to record the detail of the food and beverages consumed for the three days ( 2 weekdays and 1 weekend) and not to change their usual eating patterns. Their dietary intakes were reviewed by the researcher to clarify any issues on record. Dietary intake of energy, macronutrients and some micronutrients from all participants were analysed using Nutritionist Pro (Axxya System, Texas).

\section{ENERGY AVAILABILITY}

The mean value of energy intake, energy expenditure and fat free mass obtained were used to estimate the athletes' energy availability. Values of less than $30 \mathrm{kcal} / \mathrm{day} / \mathrm{kg}$ FFM were described as low energy availability (Reed et al. 2014),

$$
\begin{aligned}
\text { Energy Availability }= & (\text { Energy Intake-Energy Expenditure }) / \\
& \text { kg FFM (Reed et al. 2014) }
\end{aligned}
$$

\section{BLOOD COLLECTION AND PLASMA ANALYSIS}

Blood was drawn from all participants during their luteal phase of menstrual cycle (14-28 days after the first day of period). Blood samples were collected into plain tube and centrifuged at $3000 \mathrm{rpm}$ for $15 \mathrm{~min}$ at $4^{\circ} \mathrm{C}$. Following centrifugation, aliquots of plasma were transferred to labelled $1.5 \mathrm{~mL}$ Eppendorf tubes which were sent to Division of Laboratory Medicine, University Malaya Medical Centre for the analysis of estrogen. Estrogen concentration was determined using a double-antibody procedure following the method by Cummings et al. (2002).

\section{QUESTIONNAIRES}

Menstrual History Questionnaire The self-administered questionnaire was used to assess the athlete's menstrual status during the past year. Participants were asked for their age of menarche, menstrual cycle frequency (times/year) and menstrual cycle flow (days/month).

Bone-Specific Physical Activity Questionnaire (BPAQ) BPAQ was used to obtain a comprehensive account of lifetime physical activity. Participants were required to record the type, frequency and years of physical activity involvement. Independent sections for past (from one year of age) and current (previous 12 months) regular activity (activity that participant involved) were added to facilitate the analysis of the temporal and age-specific effects of mechanical loading on the skeleton. Past and current results were added to measure total BPAQ score. Ground reaction force (GRF) was available in a previous study by Weeks and Beck (2008) depending on the type of sports involved. For example, for non-body weight exercise GRF was $\leq 1.0$, track and field sport GRF 4.88, badminton sport GRF 22.07 and soccer sport GRF 13.62. Based on GRF (effective load stimulus), BPAQ score was calculated by using a calculation. The high BPAQ score means the bone receiving high mechanical stimuli during exercise.

$\mathrm{BPAQ}=[\mathrm{R}+0.2 \mathrm{R}(\mathrm{n}-1)] \times \mathrm{a}($ Weeks \& Beck 2008)

$\mathrm{R}$ is the effective load stimulus (derived from GRF testing); $\mathrm{n}$ is the frequency of participation (per week); a is the age weighting factor

(age weightings: $<10$ years $=1.2 ; 10-15$ years $=1.5 ; 15-35$ years $=1.1 ;>35$ years $=1.0$ )

\section{STATISTICAL ANALYSIS}

The results are presented as means \pm standard errors of the mean (SEM) unless otherwise stated. The distribution of data for normality was assessed using the Shapiro-Wilk test before statistical analysis. The associations of body weight, fat percentage, energy intake, energy expenditure, energy availability, estrogen level and BPAQ score with BMD were determined using the Pearson correlation. Stepwise Linear Regression was used to determine which factor best to predict BMD. Standardized $\beta$-coefficients, $\mathrm{t}$ and $\mathrm{p}$-values were reported. Data were analysed using Statistical Package for the Social Sciences version 22.0 (SPSS, Inc., Chicago, IL).

\section{RESULTS}

\section{PHYSICALS CHARACTERISTICS, MENSTRUAL STATUS, ESTROGEN, BPAQ SCORE AND BMD}

Participant characteristics, BMD and menstrual status are shown in Table 1. They were involved in team sports, athletics, racquet sports, aesthetic sports, combat sport and trained at least 5 days/week. The menstrual history questionnaire analysis classified all female athletes as eumenorrhoeic i.e. normal age of menarche, cycle frequency and cycle flow. Based on the bone analyses of 
85 female athletes, $53 \%$ of them had low bone density (z-score: $-0.59(0.06))$ and $47 \%$ showed a normal bone density (z-score: $1.06(0.2)$ ).

TABLE 1. Characteristics of participants. Values are mean \pm standard deviation (SD), $n=85$

\begin{tabular}{lc}
\hline Variables & Mean $\pm \mathrm{SD}$ \\
\hline Age (years) & $21 \pm 3$ \\
\hline Anthropometry measures & \\
Body weight (kg) & $56 \pm 9$ \\
Height (cm) & $159 \pm 0$ \\
Body mass index & $22 \pm 3$ \\
Body fat (\%) & $27 \pm 6$ \\
Menstrual Cycle and Hormone Status & \\
Age of menarche (years old) & $12 \pm 1$ \\
Cycle frequency (times/year) & $12 \pm 1$ \\
Cycle flow (days/month) & $7 \pm 2$ \\
Estrogen level (pmol/L) & $500 \pm 40$ \\
Bone Status & \\
BMD z-score $>0$ & $1.06 \pm 0.99$ \\
BMD z-score < 0 & $-0.59 \pm 0.06$ \\
BPAQ score & $26 \pm 19$ \\
\hline
\end{tabular}

\section{ENERGY INTAKE, ENERGY EXPENDITURE AND ENERGY AVAILABILITY}

Dietary intake analysis obtained from $24 \mathrm{~h}$ recall and 3 -day food record was averaged. Mean energy intake was $1291 \pm 33 \mathrm{kcal} /$ day with macronutrient distribution $53 \%$ carbohydrate, $17 \%$ protein and $34 \%$ fat (Table 2 ). The percentage of carbohydrate intake was slightly lower than the Recommended Nutrient Intake (RNI) for Malaysia (NCCFN 2005). Meanwhile both protein and fat percentage were consistent with RNI macronutrient distribution ranges. Mean carbohydrate intake ( $6 \mathrm{~g} / \mathrm{kg} /$ day $)$ was consistent with sports nutrition recommendation whilst protein intake (1 $\mathrm{g} / \mathrm{kg} /$ day) was below than the recommended value for athletes (>1.2 g/kg/day) (Burke et al. 2004). The intake of vitamin D and calcium was lower than the RNI. Energy expenditure $(1807 \pm 34) \mathrm{kcal} /$ day $)$ was lower than their energy intake which produced a low energy availability $(29 \pm 1 \mathrm{kcal} / \mathrm{day} / \mathrm{kg} \mathrm{FFM})$.

TABLE 2. Dietary Intake of the female athletes. Values are mean \pm standard error of the mean (SEM), $n=85$

\begin{tabular}{lcc}
\hline Nutrient Intake & Mean \pm SEM & RNI \\
\hline CHO $(\mathrm{g})$ & $167 \pm 4.7$ & 209 \\
Fat $(\mathrm{g})$ & $50 \pm 1.6$ & 50 \\
Protein $(\mathrm{g})$ & $55 \pm 1.8$ & 55 \\
Vitamin D $(\mu \mathrm{g} / \mathrm{d})$ & $0.5 \pm 0.2$ & 5 \\
Calcium $(\mathrm{mg} / \mathrm{d})$ & $416 \pm 17.8$ & 800 \\
Phosphorus $(\mathrm{mg} / \mathrm{d})$ & $894 \pm 35$ & 550 \\
Energy Intake $(\mathrm{kcal})$ & $1291 \pm 33$ & 2000 \\
Energy from CHO $(\%)$ & $53 \pm 0.7$ & $55-65$ \\
Energy from Fat $(\%)$ & $34 \pm 0.5$ & $25-35$ \\
Energy from Protein $(\%)$ & $17 \pm 0.3$ & $15-20$ \\
\hline
\end{tabular}

ASSOCIATION OF BMD WITH BODY WEIGHT, BODY FAT PERCENTAGE, ENERGY INTAKE, ENERGY EXPENDITURE, ENERGY AVAILABILITY, ESTROGEN LEVEL AND BPAQ SCORE

The association between BMD and variety of factors are shown in Table 3. The participants' body weight had a significant positive association with BMD $(\mathrm{r}=0.3, \mathrm{p}=0.01)$. However, there were no association between body fat percentage and BMD. Both the energy intake and energy availability were found to have no correlation with BMD. Nonetheless, it is showed a significant negative correlation ( $\mathrm{r}=-0.4, \mathrm{p}<0.001)$ between energy expenditure and BMD. The female athletes' estrogen level was $500 \pm 40 \mathrm{pmol} / \mathrm{L}$ which was lower compared to normal estrogen level (700 - 1079 pmol/L). However, there was no significant correlation between BMD and estrogen level. The mean score for the measurement of BPAQ was $26 \pm 19$ and scores below 40 were categorised as low (Weeks \& Beck 2008). There is a significant positive correlation $(\mathrm{r}=0.4, \mathrm{p}<0.001)$ between BMD and BPAQ score.

TABLE 3. Correlation analysis of the association of energy intake, energy expenditure, energy availability, body weight, body fat, BPAQ score and estrogen level with BMD

\begin{tabular}{lcc}
\hline Variable & Correlation $(\mathrm{r})$ & $p$-value \\
\hline Energy intake & 0.159 & 0.074 \\
Energy expenditure & -0.445 & 0.000 \\
Energy availability & 0.039 & 0.363 \\
Body weight & 0.276 & 0.005 \\
Body Fat & 0.124 & 0.129 \\
BPAQ score & 0.403 & 0.000 \\
Estrogen level & -0.105 & 0.169 \\
\hline
\end{tabular}

Stepwise regression analysis Using stepwise regression analysis, the variables of energy expenditure and BPAQ score were found to be significant predictors of BMD (Table 4). Energy expenditure was the single best predictor of BMD, which accounted for $19.8 \%$ of the variation in BMD. With the inclusion of BPAQ score, an additional $7.3 \%$ of variation in BMD was accounted and adjusted R2 was 0.254 . Energy expenditure showed a significant association with BPAQ score $(r=0.33, p=0.002)$.

TABLE 4. Stepwise regression analysis models predict the association of variety factors with BMD

\begin{tabular}{lcccc}
\hline Variable & Coefficient & SE & T & $P$ \\
\hline (Constant) & -2.499 & 0.620 & -4.031 & 0.000 \\
Energy expenditure & 0.001 & 0.000 & 3.498 & 0.001 \\
BPAQ Score & 0.017 & 0.006 & 2.884 & 0.005 \\
\hline
\end{tabular}

\section{DISCUSSION}

This study indicates that BMD was significantly associated with energy expenditure, body weight and BPAQ score 
in female athletes. However, there was no correlation of BMD with energy intake, energy availability, body fat percentage and estrogen level. Stepwise regression showed only energy expenditure and BPAQ score were the main factors that could predict BMD.

Female athletes in this study reported a lower energy intake than their energy expenditure which led to low energy availability, as the value obtained was less than $30 \mathrm{kcal} /$ day $/ \mathrm{kg}$ FFM. Previous studies suggested that low energy availability could be due to high pressure to obtain optimal training body weight which could also cause loss of BMD (Nichols et al. 2007) even without the deterioration of estrogen level (Ihle \& Loucks 2004). Poor energy intake, food selection and dieting habit were the main factors of insufficient carbohydrate and protein intake (Manore 2002). The present study found that the percentage of calorie intake from carbohydrate was lower than the RNI. Protein intake percentage was within the recommended range (RNI) but lower than sports nutrition recommended values when expressed as gram per kilogram body weight. Intake of calcium and vitamin D which are important for bone development was observed to be lower than the RNI which may contribute to low BMD. Women taking calcium and vitamin D supplementation regularly showed low BMD than those who did not take the supplementation (Lim et al. 2011).

Overall, this study found that energy expenditure was negatively associated, whilst body weight and BPAQ scores were positively associated with BMD. The positive association between BMD and body weight suggested that low body weight increased the chance of low BMD. This could be explained by the low energy availability due to lower energy intake than energy expenditure observed in the female athletes. Low energy availability was found to be associated with low BMD (Viner et al. 2015), however in our study there was no significant association of BMD with energy intake and energy availability. Therefore, high energy expenditure may have contributed to low BMD among the female athletes in the present study. According to Shriver et al. (2013), daily total energy expenditure for different type of sports was significantly higher than energy intake in female athletes. High energy expenditure with poor nutrient replacement during exercise could enhance low calcium level in the body by the removal of calcium from the bone and muscle contraction activity during exercise (Quah et al. 2009). Long duration of physical activity was also reported to increase calcium loss in the bone (Cavanagh at el. 2007).

BPAQ score $(26 \pm 9)$ was lower than normal value (40) which showed that the participants were exposed to low mechanical bone loading during physical activity. The present study suggested that low bone mechanical loading was associated with low BMD which might be caused by low impact activities leading to low BMD among these female athletes. This finding is consistent with Scofield and Hecht (2012) study which reported that high bone mechanical loading was acknowledged widely to be advantageous for long-term bone health.
High mechanical loading sport produced osteogenic effects on bone, which occurred when mechanical stimuli was present to stimulate bone formation and conversely, degraded when such stimuli was absent. Similarly, one study using high impact exercise consisting of walking, running, jumping, aerobic dancing and stair climbing had been found to increase bone serum biomarkers in females (Adami et al. 2008). High impact exercise involving body weight or known as weight bearing exercise may help to strengthen the bone (Erickson \& Vukovich 2010; Lester et al. 2009). Thus, the athletes involved in anti-gravitational or long distance sports are advised to do an extra training session that involved high osteogenic activity particularly weight-bearing exercise.

Low body weight also might impair athletes' body fat percentage and subsequently lead to low estrogen secretion (De Souza et al. 2008). Declining estrogen levels can increase the lifespan of osteoclasts, leading to bone resorption in the female. Estrogen is needed for proper development of epiphyseal growth plates in bone (Kassem 1997) and its secretion depends on secretion of luteinizing hormone in the blood (Loucks 2003). Low luteinizing hormone leads to reduce estrogen release which negatively affecting bone formation and resorption and finally cause net bone loss (reduced osteoblast, increased osteoclast) in amenorrheic athletes (De Souza et al. 2008). Estrogen level among the female athletes in this study was lower than normal range. However we found no correlation between estrogen level and BMD. This was supported by the finding from as study by Ihle and Loucks (2004) who suggested that low BMD could occur without the deterioration of estrogen concentration. Using a stepwise regression analysis, it was found that only energy expenditure and BPAQ score were the main factors that could predict BMD among female athletes.

To date, the published data on the factors associated with bone quality which were limited to body composition, eating disordered, menstrual irregularity and calcium intake had focused on elite female athletes (Quah et al. 2009). The number of women competing in sports at various levels had increased for the past years, therefore, there was a need to look at their bone status and possible associated factors such energy availability, estrogen level and osteogenic effect that may impact their bone health. However, this is a cross sectional study which allow only association between factors and BMD level and does not allow causal relationship to be established. The results obtained were from the Lembah Pantai area may also limit generalization of study findings.

\section{CONCLUSION}

In conclusion, high energy expenditure, low body weight and low bone mechanical loading activities were associated with low BMD among female athletes. This study also suggests that energy expenditure and BPAQ score were the main factors that predict BMD. These factors are very important to be considered when planning for training 
program which should involve high impact exercises and simultaneously a balance diet to meet the energy requirement for minimizing the risk of low BMD among female athletes.

\section{ACKNOWLEDGEMENTS}

This project was funded by University of Malaya Postgraduate Research Grant (PG128-2014B). A special thank also goes to all participants for their cooperation and support during this study.

\section{REFERENCES}

Adami, S., Gatti, D., Viapiana, O., Fiore, C.E., Nuti, R., Luisetto, G. \& Group, B.S. 2008. Physical activity and bone turnover markers: A cross-sectional and a longitudinal study. Calcified Tissue International 83(6): 388-392.

Arieli, R. \& Constantini, N. 2012. Energy balance among female athletes. Harefuah 151(2): 82-85, 128.

Cavanagh, P.R., Licata, A.A. \& Rice, A.J. 2007. Exercise and pharmacological countermeasures for bone loss during long duration space flight. Gravitational and Space Research 18(2): 39-58.

De Souza, M.J., West, S.L., Jamal, S.A., Hawker, G.A., Gundberg, C.M. \& Williams, N.I. 2008. The presence of both an energy deficiency and estrogen deficiency exacerbate alterations of bone metabolism in exercising women. Bone 43(1): 140-148.

Dwyer, J., Eisenberg, A., Prelack, K., Song, W.O., Sonneville, K. \& Ziegler, P. 2012. Eating attitudes and food intakes of elite adolescent female figure skaters: A cross sectional study. Journal of the International Society of Sports Nutrition 9(1): 53.

Erickson, C.R. \& Vukovich, M.D. 2010. Osteogenic index and changes in bone markers during a jump training program: A pilot study. Medicine and Science in Sports and Exercise 42(8): 1485-1492.

Hall, K.D., Heymsfield, S.B., Kemnitz, J.W., Klein, S., Schoeller, D.A. \& Speakman, J.R. 2012. Energy balance and its components: implications for body weight regulation. The American Journal of Clinical Nutrition 95(4): 989-994.

Ihle, R. \& Loucks, A.B. 2004. Dose-response relationships between energy availability and bone turnover in young exercising women. Journal of Bone and Mineral Research 19(8): 1231-1240.

Ismail, M., Wan-Nudri, W. \& Zawiah, H. 1997. Energy expenditure studies to predict requirements of selected national athletes. Malaysia Journal of Nutrition 3: 71-81.

Kassem, M. 1997. Cellular and molecular effects of growth hormone and estrogen on human bone cells. Apmis 105(S71): 7-30.

Lester, M.E., Urso, M.L., Evans, R.K., Pierce, J.R., Spiering, B.A., Maresh, C.M. \& Nindl, B.C. 2009. Influence of exercise mode and osteogenic index on bone biomarker responses during short-term physical training. Bone 45(4): 768-776.

Lewiecki, E.M., Watts, N.B., McClung, M.R., Petak, S.M., Bachrach, L.K., Shepherd, J.A. \& Downs Jr., R.W. 2004. Official positions of the international society for clinical densitometry. The Journal of Clinical Endocrinology \& Metabolism 89(8): 3651-3655.

Lim, C., Omar-Fauzee, M. \& Rosli, M. 2011. The body dissatisfaction among female athletes and non-athletes in Malaysia. Journal of Asia Pacific Studies 2(1): 55-69.
Loucks, A.B. 2003. Energy availability, not body fatness, regulates reproductive function in women. Exercise and Sport Sciences Reviews 31(3): 144-148.

Manore, M.M. 2002. Dietary recommendations and athletic menstrual dysfunction. Sports Medicine 32(14): 887-901.

McClung, J.P., Gaffney-Stomberg, E. \& Lee, J.J. 2014. Female athletes: A population at risk of vitamin and mineral deficiencies affecting health and performance. Journal of Trace Elements in Medicine and Biology 28(4): 388-392.

NCCFN. 2005. Recommended Nutrient Intakes for Malaysia. A Report of the Technical Working Group on Nutritional Guidelines. National Coordinating Committee on Food and Nutrition, Ministry of Health Malaysia, Putrajaya.

Nichols, D.L., Sanborn, C.F. \& Essery, E.V. 2007. Bone density and young athletic women. Sports Medicine 37(11): 10011014.

Papadopoulou, S.K., Gouvianaki, A., Grammatikopoulou, M.G., Maraki, Z., Pagkalos, I.G., Malliaropoulos, N. \& Maffulli, N. 2012. Body composition and dietary intake of elite crosscountry skiers members of the greek national team. Asian Journal of Sports Medicine 3(4): 257-266.

Quah, Y.V., Poh, B.K., Ng, L.O. \& Noor, M.I. 2009. The female athlete triad among elite Malaysian athletes: prevalence and associated factors. Asia Pacific Journal of Clinical Nutrition 18(2): 200-208

Rauh, M.J., Nichols, J.F. \& Barrack, M.T. 2010. Relationships among injury and disordered eating, menstrual dysfunction, and low bone mineral density in high school athletes: A prospective study. Journal of Athletic Training 45(3): 243 252.

Reed, J.L., De Souza, M.J., Kindler, J.M. \& Williams, N.I. 2014. Nutritional practices associated with low energy availability in Division I female soccer players. Journal of Sports Sciences 32(16): 1499-1509.

Scofield, K.L. \& Hecht, S. 2012. Bone health in endurance athletes: Runners, cyclists, and swimmers. Current Sports Medicine Reports 11(6): 328-334.

Shriver, L.H., Betts, N.M. \& Wollenberg, G. 2013. Dietary intakes and eating habits of college athletes: Are female college athletes following the current sports nutrition standards? Journal of American College Health 61(1): 10-16.

Viner, R.T., Harris, M., Berning, J.R. \& Meyer, N.L. 2015. Energy availability and dietary patterns of adult male and female competitive cyclist with lower than expected bone mineral density. International Journal of Sport Nutrition and Exercise Metabolism 25(6): 594-602.

Weeks, B.K. \& Beck, B.R. 2008. The BPAQ: A bone-specific physical activity assessment instrument. Osteoporosis International 19(11): 1567-1577.

Yang, L-C., Lan, Y., Hu, J., Yang, Y-H., Zhang, Q., Huang, Z-W. \& Piao, J-H. 2010. Relatively high bone mineral density in Chinese adolescent dancers despite lower energy intake and menstrual disorder. Biomedical and Environmental Sciences 23(2): 130-136.

Nur Syamsina Ahmad*, Jadeera Phaik Geok Cheong \& Sareena Hanim Hamzah

Sports Centre, University of Malaya 50603 Kuala Lumpur, Federal Territory Malaysia 
Mohamad Shariff A. Hamid

Sports Medicine Unit, Faculty of Medicine

University of Malaya

50603 Kuala Lumpur, Federal Territory

Malaysia
*Corresponding author; email: sunsinar@hotmail.com

Received: 16 March 2017

Accepted: 25 May 2017 